a "prosperous termination" of thoir desired end of air pollution, they were well on the way to their ultimate goal of "blue skies and pink lungs". Incidental to the problems faced is the question of solid fuel distribution and supplies; this was discussed by Mr. E. Otty, hoad of Special Projects Branch, National Coal Board, and Mr. W. H. Bourne, manager, National Fedoration of Coke Distributors' Associations.

One session of the Conforence was devoted to the subject of air pollution and mortality. Mr, A. J. Wicken, head of Health Surveys, AGB Research, Ltd., stated that the findings of a rocont survey in north-east England indicated that both lung cancer and bronchitis mortality are associated with air pollution. Speaking of odour control by eatalytic combustion, Mr. E. Betz directed attention to the fact that many industrial effuents were not, as yet, covored by real legislation, it being left to local authorities to try to enforco production of clean and odour-free air; he claimed that, of available methods of removing organic fume nuisances, catalytic combustion was the most efficient; this could solve odour problems in the chemical industry, in nitric acid manufacture and in the oven industry among many other applications. The Belgian method for dealing with road vohicle pollution was described by Mr. E. J. Coucke, director, Fund for Study and Research on Road Safoty, Brussels. This method is based on a closely integrated system of technical inspection of motor vehicles, involving fifty inspoction stations, oach equipped with a smoke-meter to measure diesel smoke density. Mr. Coucke went on to describe an intorosting experiment designed to reduco rate of emission of carbon monoxide by petrol engines, which was conducted with vehicles used by tho Paris Profecture of Police; this is essentially a matter of procise adjustment of carburettors ajmed at the systematic reduction of the production of this toxic gas while the motor is idling. His paper on Belgian practice in the matter of pollution of air by road vehicles is comprchensivo and worthy of study.

It was perhaps inevitable that in such a Conference as this, new horizons in domestie heating should command attontion, and the now familiar propaganda of what each of the competitivo fuel industries has to offer in various heating systems, and what the domestie consumer in the United Kingdom may look forward to in the near future to realize efficient, economical and completely smoko-freo warmth in the home, was characteristically conveyed by Mr. H. R. Brewster (Shell-Mox and B.P., Ltd.) repre. sonting oil intorests; by Mr. R. N. Bruce (chairman,
South Eastern Gas Board), concerned with gas (not excluding North Sea prospoets); and by Dr. W. Reid (chairman, Northumberland and Durham Division, National Coal Board) in discussing steps being taken to promote higher standards of home heating apparatus, hence clean air, by production of adequate supplies of smokeless fuels, by stimulating design and production of new and, as near as possible, automatic appliances, and by district heating. The case for electricity was ably put by Mr. C. T. Melling (deputy chairman, the Electricity Council).

Mr. J. Hodgson spoko on industrial aspects of dust collection and solection of proper equipment to deal with tho particular factory product or plant involved; his paper doalt, inter alia, with methods of settling chambers, inertial collectors (cyclones), fabric collectors, wet colloctors and electrostatic precipitators. On the controversial subject of chimney heights, Mr. S. C. Beaumont (chief smoke inspector, Birmingham) roferrod to the Memorandum of Chimney Heights issued by the Ministry of Housing and Local Government which, although wel. comed, did not provide all the answers to problems raised by conflicting interests in this matter, and which oven the Clean Air Act failed to satisfy; he claimed that ". . . for reducing pollution from sulphur dioxide, tall chimneys apparonlly were the present answer, but the best remedy would be the use of low-sulphur content fuels". The Conference concluded by considering somo unresolved problems in air pollution. In this connexion there was an important contribution by Mr. F. E. Iroland, chief alkali, etce, works inspoctor of England and Wales, who described some of the difficulties still with us concerning nuisances relating to sulphuric acid, nitric acid, ceramic industrios, iron and steel, non-ferrous metals, metal recovory, and lime works; he added: "Tho search for solutions and improvements to industrial emissions continues unabated, both nationally and internationally".

The publicity afforced to the vital subject of clean air is in itself a healthy sign. The work of this Eastbourne Conference is a credit to all concemed. Britain is facing up to the problems involved in combating air pollution, from whatever source it may derivo, and it is encouraging to know that so many othor countrios are doing the same. The first congress of tho nowly formed International Union of Air Pollution Prevention Associations will be held in London during October $3-7,1966$; somo details of this desirable function are given in a recent number of Smokeless Air (36, No. 135; Autumn 1965. Pp. 13, 18. London: National Society for Clean Air. 3s.).

\title{
REACTIVITY OF PHOTO-EXCITED ORGANIC MOLECULES
}

\begin{abstract}
$\mathrm{T}$ HE Solvay Institute for Chemistry was foundod in 1913, at a time when international conforences in science were comparatively rare. Since that time, as with other aspects of the rising tide of scientific knowledge, methods of communication have become much more numerous. Discussion meetings, conferences and symposia are being organized all over the world, to promote the advancerment of knowledge on broad or narrow fronts of science. At the present time, those who are concerned with such organizing havo to docide a number of questions, which it is useful to keep in mind when considering the outeome of any meeting of more than purely local appeal. When the primary object is to bring together and intograte rolated advances in different directions, as has always been the aim of Solvay confer. ences, the timing of the meeting, and the choice of those eligible to attend it, nocd to be planned with much greater care than is needed for more omnibus gatherings, at which the main object is to promote binary and ternary
\end{abstract}

collisions of minds more or less at randorn, but in a fruvourable environment. If an inlegrating theme is aimed at, its selection must now also pay some regard to any related discussions at an international level, held. or due to be held over a perjod which may extend ovor several years. Finally, the decision whethor to publish Proceedings of a conference, to be of real service to a much widor eirele of roaders than those who actually attonded it, calls for responsiblo judgment. This may not be easy, in view of the flood of seientific literature already available.

In the broad range of possible kinds of conferences, the pattern chosen by the Solvay Institute is one of the highest selectiveness in the choice of those invited to take part in the week's discussions. Only one or two pre-printed contributions wore considered each day. In the present instance these were by C. A. Coulson, R. Daudel, G. S. Hammond, E. Havinga, G. Porter, G. O. Schenk, G. M. J. Schmidt and N. C. Yang. The printed texts were not restricted in length, in order to 
permit each author to indicate the present problems of his own speciality, on an extensive perimeter. In addition to the authors and the members of the Scientific Council of the Solvay Institute, a limited number of leading scientists concerned with this field were also invited to attend. On this rather exclusive basis, those present found it feasible to diseuss and defino thoir difficulties, as well as to communicate their progress, without undue pressure from othor speakors more anxious to communicate, than to attempt in common any Socratic assessmont of ignoranco. As in the case of other recent meetings of the Solvay Institute, on inorganic structural chemistry (1956), on nucleoproteins (1959) and on energy transfer in gases (1962), the invited papers and considered discussion contributions resulting from the compact team-work of the prosent mooting will bo published in full, us soon as possible.

At this meeting some highly suggestive theoretical considerations about photo-excited molecules attracted much discussion. Advances in theoretical chemistry indicate that interactions between excited molecules may differ markedly from the situation described by tho more familiar force fields and potontial energy surfaces for molecules in the ground stato. Comparod with these, even the analogues of van der Waals' forces are likely to be of considerably longer range between excited species. In a molccular encounter, at the stage near what would bo the transition state for unexcited molecules, more intense interastions likewise call for profound modifications in thoir doseription when they refer to olectronically excited species. A goneral enlargement of the 'molecule volume' may be anticipated, within which the distribution of electronic charge can affect the course of chemical reaction between excited species.

This general inference points to a number of novel directions for theoretical and experimental research. Quite generally, even when apparently non-bonded, the influence of neighbouring molecules on a specific molecular reaction can be much more profound, when this involves photo-excited species, than for molecules in the ground state. A particular instance of the controlling influence of neighbours, which was extensively discussed at the meeting, but for which there still remains much to be clarified, refers to photo-chemical reactions in the crystal. line state, or in solid solution.

Striking solvent effects on reactions between excited molecules may be closely related to this general principlo, and several instances were discussed. Again, effects of prossure in determining the relative role of alternative chemical reactions should be much more prominent and distinctive, in favourable cases, than can normally be expected for reactions in the ground state.

The complexity of molecules the photo-chemical reactions of which can now be studiod exporimentally has incroased in recent years to a notablo extent, through the development of new methods of photo-excitation, and the use of various refined methods of chemical identification of the products. This has given new impetus to highly suggestive researches on problems such as the transmission of excitation energy within a polyatomic molecule, resulting from primary absorption of photons, or from irradiation by $\gamma$-rays or particlos. Rogions of a photo-oxeited molecule that may undergo quite diverse reaction can be examined on a selective basis. In addition to the great scientific interest of researches in this general direction, the technological mastery of economic production by photo-chemical means of quito complex molecules offers suggestive possibilities; though these were not, diseussed at any length at the meeting, they seem likely to attract more attention to this field in the future.

Calculations of the distribution of electron densities in molecules in their ground state can now be made with considerable confidence in favourablo instances. Howevor, there was some diseussion about the extont to which such density distribution can guide assessments of reactivity of excited states. Novel ideas about oharge transfer between excited molecules, put forward at the meeting by R. S. Mulliken, providod furthor fuscinating glimpses of important future work in a field which promises to grow rapidly.

A. R. UBBELOHDE

\section{SCHISTOSOMIASIS}

$\mathrm{M}$ ALARIA has been aptly called 'public enemy No. 1' and the title 'public enemy No. 2' might well be given to schistosomiasis, a lingering and often fatal disease of man and other animals including farm stock. The disease is caused by parasitic tremalode flatworms belonging to the genus Schistosoma or Bilharzia. The latter name cornmemoratos Dr. Bilharz, who first discovered the eggs of the parasite in Egypt and who was a pioncer in researeh on "this trematode and on the disease it causes. Species of this genus, unlike other parasitic trematodes, are unisexual and live, not in the digestive tracts of their hosts as do many parasitic trematodes, but in the blood vessels: for this reason they are often called 'blood flukes'.

It is indeed good news that the Rockefeller Foundation, continuing its policy, so fruitful in the past, of giving financial aid to studies of the grave diseases that plague the world, has deeided to undertake field investigations of sehistosomiasis. The Foundation has been interested in sehistosomiasis for 40 yoars. These investigations will be carried out on the small island of Santa Lucia in the Windward Islands; the Government of the Islands has also decidod to give financial aid to these investigations. Schistosomiasis causes incalculable suffering and conomic loss. It is estimated that some two hundrod million pcople suffer from it in Egypt, Africa, South Amorica, the Caribboan Islands, India and the Near and Far East. It has crippled large human populations and also agricultural progress, for some species of those trematodes infect farm stock. Egypt has boon called the 'cradle' of the disease, because formerly it was prevalent there (the eggs of these trematodes have been found in Egyptian mummies dating from 1,000 B.C.).

Schistosomiasis is a disease that especially affects agricultural peoples who work on irrigated land or irrigation systems. Man is infected by larval forms of the tromatodes (corcariae) which develop in certain species of aquatic snails living in streams, pords, lakes and irrigation systems in which he may work or bathe. The cercariae are able to penetrate human skin and enter the blood stream, which carries them to the blood vessels of the abdomen. Here they settle down and become sexually mature and lay spined eggs which work their way out of the infected person through the wall of the intestine or bladder into the faeces or urine. In so doing they cause bleeding from, and other forms of damage to, the walls of tho bladder or intestine. Human faeces and urine contarninated with the eggs of tho tromatodes are frequently discharged into local waters. The eggs liberate larvae into the water which ponetrate into snails living under water and develop inside the snails into cercarial larvae which leave the snails and can subsequently infect man.

It will be clear, therefore, that the disease is, in this sense, man-made.

Control of the disease aims at: (1) Protection of the human skin from the cercariae by wearing suitable clothing or by avoiding infected waters. (2) Destruction of the species of snails involved by means of chemical sub- 